\title{
Borrelia burgdorferi induces a type I interferon response during early stages of disseminated infection in mice
}

\author{
Mary M. Petzke ${ }^{1 *}$, Radha lyer ${ }^{1}$, Andrea C. Love ${ }^{1,3}$, Zoe Spieler $^{1}$, Andrew Brooks ${ }^{2}$ and Ira Schwartz ${ }^{1}$
}

\begin{abstract}
Background: Lyme borrelia genotypes differ in their capacity to cause disseminated disease. Gene array analysis was employed to profile the host transcriptome induced by Borrelia burgdorferi strains with different capacities for causing disseminated disease in the blood of $\mathrm{C} 3 \mathrm{H} / \mathrm{HeJ}$ mice during early infection.

Results: $B$. burgdorferi B515, a clinical isolate that causes disseminated infection in mice, differentially regulated 236 transcripts $(P<0.05$ by ANOVA, with fold change of at least 2). The 216 significantly induced transcripts included interferon (IFN)-responsive genes and genes involved in immunity and inflammation. In contrast, B. burgdorferi B331, a clinical isolate that causes transient skin infection but does not disseminate in $\mathrm{C} 3 \mathrm{H} / \mathrm{HeJ}$ mice, stimulated changes in only a few genes (1 induced, 4 repressed). Transcriptional regulation of type I IFN and IFN-related genes was measured by quantitative RT-PCR in mouse skin biopsies collected from the site of infection $24 \mathrm{~h}$ after inoculation with B. burgdorferi. The mean values for transcripts of Ifnb, CxCl10, Gbpl, Ifit1, Ifit3, Iff7, MxI, and Stat2 were found to be significantly increased in B. burgdorferi strain B515-infected mice relative to the control group. In contrast, transcription of these genes was not significantly changed in response to B. burgdorferi strain B331 or B31-4, a mutant that is unable to disseminate.
\end{abstract}

Conclusions: These results establish a positive association between the disseminating capacity of B. burgdorferi and early type I IFN induction in a murine model of Lyme disease.

Keywords: Lyme disease, Type I interferon, Bacterial pathogenesis, Mouse model

\section{Background}

Lyme disease, the most common vector-borne infection in North America [1], is caused by the spirochete Borrelia burgdorferi and transmitted through the feeding of infected Ixodes species ticks [2]. Approximately $70-80 \%$ of patients develop a characteristic skin lesion, erythema migrans (EM), at the site of inoculation that is characterized by an influx of immune cells, predominantly $\mathrm{T}$ lymphocytes, macrophages/monocytes, and dendritic cells $[3,4]$. If left untreated with recommended antibiotic therapy [5], sequelae of Lyme disease can include rheumatologic, neurologic and cardiac symptoms following hematogenous dissemination of the spirochete from the

\footnotetext{
* Correspondence: mary_petzke@nymc.edu

'Department of Microbiology and Immunology, New York Medical College, Valhalla, New York, USA

Full list of author information is available at the end of the article
}

site of inoculation in the skin to target tissues such as the joints, central nervous system and heart [6].

The potential for dissemination is likely dependent on multiple host and pathogen factors, including the existence of diverse B. burgdorferi genotypes that can be classified based on a number of molecular characteristics, including restriction fragment-length polymorphism of the 16S-23S ribosomal DNA spacer region (ribosomal spacer type; RST) and the sequence of outer surface protein C (OspC) [7]. Numerous studies have established an association between genotype and the capacity to cause invasive disease. RST1 strains are more likely to cause disseminated infection in Lyme disease patients, whereas RST2 and RST3 strains are less frequently detected in the blood [8-11]. Four of the 16 identified OspC genotypes were found to account for $80 \%$ of cases of disseminated Lyme disease in the Northeastern United States, including both of the OspC genotypes corresponding to 
RST1 (OspC A and B); in contrast, only one of the four OspC genotypes associated with RST2 (OspC K), and one of the ten OspC genotypes associated with RST3 (OspC I), were identified as highly invasive [11]. These correlative data were confirmed by direct experimental validation using a murine model of Lyme borreliosis; infection of $\mathrm{C} 3 \mathrm{H} / \mathrm{HeJ}$ mice with $\mathrm{RST} 1$ strains resulted in significantly higher spirochete loads in tissue, and more severe arthritis and carditis, than did infection with RST3 isolates, some of which did not disseminate from the inoculation site $[12,13]$.

B. burgdorferi elicits the production of both pro- and anti-inflammatory cytokines via recognition of spirochetal cellular components by cells of the host's innate immune system [14-17]. The induced cytokine profile may have a critical impact on disease outcome, as a strong pro-inflammatory response early in infection appears to mediate host protection in both mice and in Lyme disease patients [4, 18-21]. Intriguingly, expression profiling of a murine macrophage cell line stimulated with diverse $B$. burgdorferi clinical isolates revealed no genotype-specific differences in mRNA or protein levels for a number of pro-inflammatory cytokines known to be associated with Lyme disease pathogenesis [22]. Similar results were observed when comparing $B$. burgdorferi clinical isolates of varying genotype using an ex vivo human peripheral blood mononuclear cell (PBMC) model and measuring secreted cytokine proteins [23]. However, the latter study identified a correlation between the induction of IFN- $\alpha$, a type I interferon (IFN), and B. burgdorferi genotype; significantly higher levels of IFN- $\alpha$ were elicited by strains with a greater capacity for dissemination [23]. This finding was corroborated by a separate study in which RST1 isolates induced significantly greater IFN- $\alpha$ production by human PBMCs relative to RST3 isolates [24]. Type I IFNs have also been detected in serum and in blister fluids raised over EM lesions of Lyme disease patients and serum levels of IFN- $\alpha$ were found to be significantly higher in patients with multiple EM skin lesions, an indication of disseminated Lyme disease, relative to patients with a single EM lesion [4]. In addition, type I IFNs and IFN-responsive genes are expressed in the joints of B. burgdorferi-infected mice and play a crucial role in the subsequent development of Lyme arthritis $[25,26]$.

The present study was designed to identify host transcriptional alterations, including those of IFN-responsive genes, elicited in a murine model of Lyme borreliosis. Gene array analysis was employed to profile global gene expression changes induced by B. burgdorferi strains of varying genotypes in mouse whole blood at 14 days post-inoculation. Additionally, transcription of type I IFNs and IFN-related genes was measured $24 \mathrm{~h}$ post-infection in mouse skin at the site of intradermal inoculation with various $B$. burgdorferi strains.

\section{Results \\ Differential infection outcomes in mice inoculated with \\ B. burgdorferi clinical isolates}

$\mathrm{C} 3 \mathrm{H} / \mathrm{HeJ}$ mice were inoculated with B. burgdorferi $\mathrm{B} 515$, an RST1 strain that causes disseminated infection in mice [13] or B. burgdorferi B331, an RST3A strain that is unable to disseminate from the skin [13]. Forty-four (97.8\%) of the 45 blood and tissue samples collected on day 28 from mice infected with B. burgdorferi B515 were positive by culture (Table 1 ). In contrast, spirochetes could not be recovered from any tissues collected from mice infected with B. burgdorferi B331 (0/60; 0 \%). Notably, culture positivity from all individual tissues assessed was significantly higher for mice infected with B. burgdorferi B515 as compared with B. burgdorferi B331 $(P<0.001)$ (Table 1$)$. To confirm disseminated infection in B515-infected mice, development of joint swelling as an indicator of clinically apparent arthritis was monitored by measurement of the ankle-joint diameter using a digital caliper on days 7, 14, 21 and 28 postinfection. The average ankle joint diameters were significantly greater for mice infected with B. burgdorferi B515 as compared to mice infected with B. burgdorferi B331 or medium-inoculated controls at each of these time points $(P<0.0001)$ (Fig. 1). Taken together, these results confirm the development of disseminated infection in mice inoculated with B. burgdorferi B515, but not in B. burgdorferi B331-inoculated animals.

\section{B. burgdorferi elicits genotype-dependent transcriptional profiles in mouse blood}

Gene array analysis was performed in order to examine the host global transcriptome changes elicited by B. burgdorferi in blood. RNA was isolated from whole blood collected on day 14, when disseminated infection could be confirmed by culture of ear biopsies. A total of 239 transcripts was defined as differentially regulated based on having a $P$ value of $<0.05$ and foldchange of at least 2 relative to the control group. The

Table 1 Culture of B. burgdorferi from tissue specimens of infected mice

\begin{tabular}{llllll}
\hline \multirow{5}{*}{} & \multicolumn{4}{l}{ Number of samples with positive cultures/number tested (\%) } \\
\cline { 2 - 6 } & Day 14 & Day 28 & & \\
\cline { 2 - 6 } & Ear & Ear & Skin $^{a}$ & Bladder & Joint $^{b}$ \\
\hline B515 $^{c}$ & $15 / 15(100)$ & $12 / 12(100)^{d}$ & $13 / 14(92.9)$ & $14 / 14(100)$ & $5 / 5(100)$ \\
B331 & $0 / 15(0.0)$ & $0 / 15(0)$ & $0 / 15(0.0)$ & $0 / 15(0)$ & $0 / 5(0)$ \\
\hline
\end{tabular}

${ }^{a}$ Skin biopsy was collected from the inoculation site

${ }^{b}$ Joints were cultivated from one mouse per subgroup

'One mouse in the B515-infected group died between Day 14 and Day 28

${ }^{d}$ Two samples were contaminated 


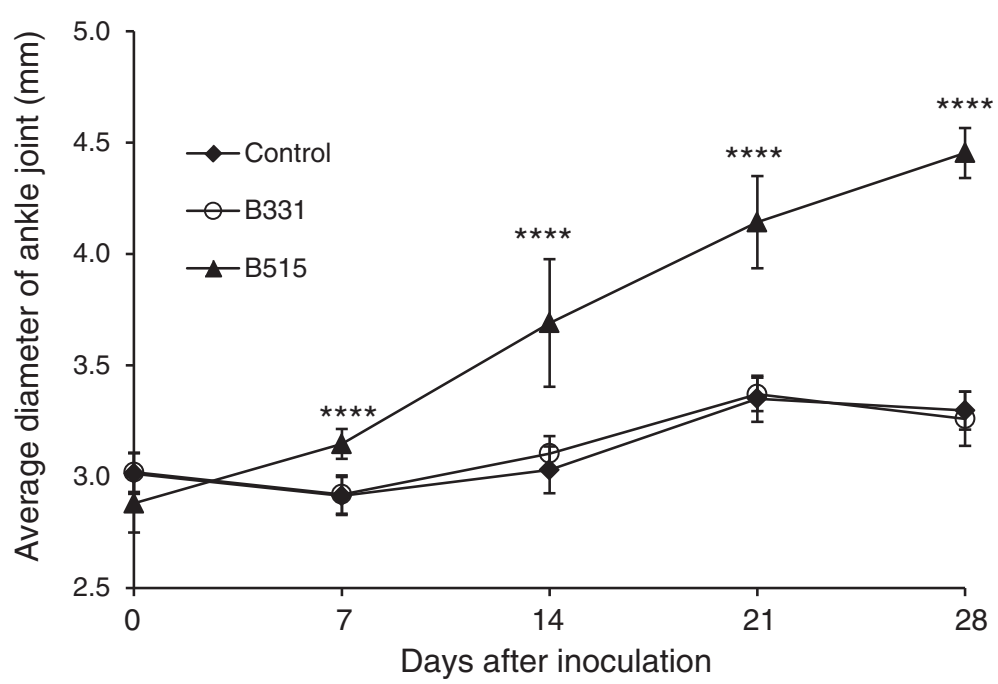

Fig. 1 Arthritis development in infected mice. Groups of $15 \mathrm{C} 3 \mathrm{H} / \mathrm{HeJ}$ mice were inoculated intradermally by needle with $1 \times 10^{4}$ spirochetes of B. burgdorferi strains B515 or B331, or with medium (control). Tibiotarsal joints were measured on days $0,7,14,21$, and 28 post-infection. Measurements are shown as the mean value of each experimental group, with bars indicating the standard deviation. ${ }^{* * *}, P<0.0001$ relative to the control and B331-infected groups

response to B. burgdorferi B515 included 236 differentially regulated transcripts (216 induced, 20 repressed). In contrast, B. burgdorferi B331 stimulated changes in relatively few transcripts (1 induced, 4 repressed); this result was not unexpected, as spirochetes could not be recovered from the tissues of any of the B. burgdorferi B331-infected mice (Table 1). The 239 differentially regulated transcripts were subjected to hierarchical clustering based on both transcript (probe set) and experimental condition (Fig. 2). Samples from mice that had been infected with B. burgdorferi B515 displayed similar transcriptional profiles and clustered together. In contrast, samples from B. burgdorferi B331-infected mice formed a second cluster together with samples from medium-inoculated control animals.

To validate the expression values generated by gene array, transcript levels for five genes were assessed by real-time RT-PCR (Table 2). Although the absolute values obtained by gene array and RT-PCR varied, a similar trend in transcriptional expression was observed by both methods for all of the genes assayed. In summary, these findings demonstrate that transcriptional changes in mouse blood vary according to the infecting Borrelia strain.

\section{B. burgdorferi induces expression of inflammatory and anti-microbial transcripts during disseminated infection including IFN-responsive genes}

Selected induced and repressed transcripts involved in the immune response are presented (Tables 3 and 4). B. burgdorferi B515 elicited elevated expression of genes with defined roles in antimicrobial defense, remodeling of the extracellular matrix, dermal inflammatory conditions, innate immunity, B cell activation and the development of humoral immunity (Ighg) and the generation of tolerogenic dendritic cells (Clec4a2) [27]. Among the most highly induced transcripts were lactotransferrin (Ltf); cathelicidin antimicrobial peptide (Camp) and its receptor, formyl peptide receptor 2 (Fpr2); versican (Vcan); chitinase 3-like 3 (Chi3l3);

Table 2 Real-time RT-PCR validation of gene array results

\begin{tabular}{|c|c|c|c|c|c|c|}
\hline \multirow[b]{2}{*}{ Probe set ID } & \multirow[b]{2}{*}{ Gene symbol } & \multirow[b]{2}{*}{ Gene name } & \multicolumn{2}{|l|}{ B515 } & \multicolumn{2}{|l|}{ B331 } \\
\hline & & & $\overline{\text { Array }^{\mathrm{a}}}$ & $\overline{R T-P C R^{a}}$ & $\overline{\text { Array }}$ & RT-PCP \\
\hline 1419691_at & Camp & cathelicidin antimicrobial peptide & 4.0 & 6.5 & -1.1 & -1.2 \\
\hline 1418722_at & $\mathrm{Ngp}$ & neutrophilic granule protein & 5.6 & 25.6 & -1.2 & 1.8 \\
\hline 1420549_at & Gbp1 & guanylate binding protein 1 & 1.9 & -1.1 & 1.1 & -1.7 \\
\hline 1427256_at & Vcan (Cspg2) & versican & 4.1 & 12.2 & 1.2 & 1.9 \\
\hline 1423466_at & $\mathrm{Ccr} 7$ & chemokine (C-C motif) receptor 7 & -1.9 & -1.2 & -1.2 & 1.0 \\
\hline
\end{tabular}

${ }^{a}$ Mean fold change values relative to medium-inoculated control group 


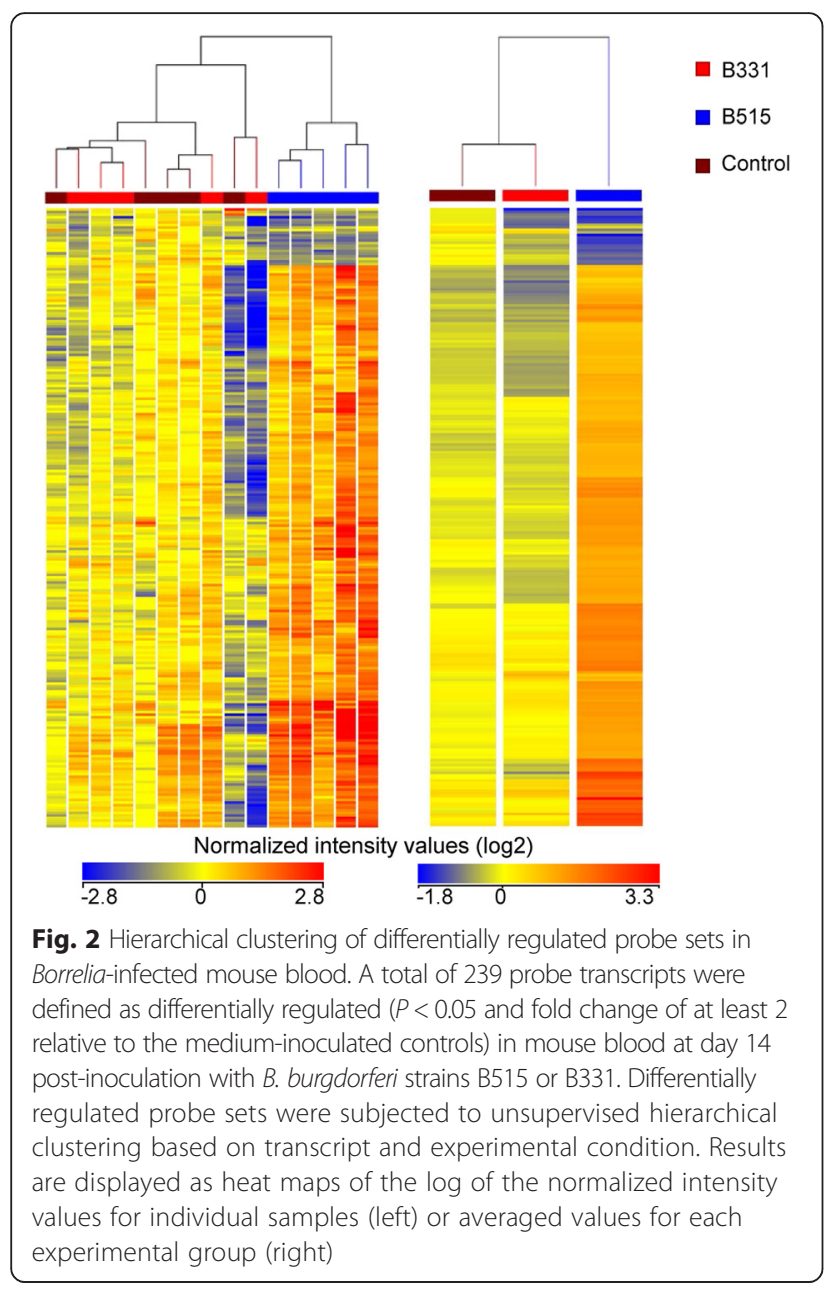

and lipocalin 2 (Lcn2). Also included was the gene encoding TLR13, which has recently been identified as a receptor for bacterial ribosomal RNA [28-30], as well as genes encoding two proteins (TLR2 and CD14) with established roles in the innate immune response to B. burgdorferi lipoproteins [31-33]. Two of the induced transcripts (Ifitm2 and Ifitm6) contained the term "interferon induced" in the gene title. A database search for interferon-responsive genes identified 92 of the 216 (42.6\%) B515-induced transcripts as interferon responsive (http:www.interferome.org).

Twenty transcripts were repressed by $B$. burgdorferi B515 (Table 4). Of these, two transcripts (Pfn2, profilin and Tnfrsf13c, tumor necrosis factor receptor superfamily, member 13c) were also repressed by $B$. burgdorferi B331. Pfn2 has an annotated function in cytoskeleton organization and Tnfrsf13c is involved in B-cell homeostasis. Other transcripts involved in humoral immunity were repressed by B515; these included Fcer2a (Fc receptor, IgE, low affinity II, alpha polypeptide), Ighv14-2 (immunoglobulin heavy variable 14-2), and Ebf1 (early B cell factor).
Induction of type I IFN and IFN-responsive genes by B. burgdorferi in skin correlates with capacity for dissemination

Expression of IFN-responsive genes has been shown to be a critical factor in the development of arthritis in a susceptible mouse model of Lyme borreliosis $[25,26]$. The observation that a type I IFN response can be detected in the blood at day 14 post-inoculation, however, suggested a potential role for type I IFNs during earlier stages of infection. In order to evaluate the differential expression of type I IFN-related genes at the site of inoculation in mouse skin, groups of nine mice were inoculated with $1 \times 10^{4}$ spirochetes of B. burgdorferi strains B515, B331, or B31-4, a derivative of type strain B31 (RST1) that lacks all linear plasmids, is unable to disseminate in mice [34] and does not induce a type I IFN response by human peripheral blood mononuclear cells [23]. Skin biopsies were collected 24 h post-inoculation for RNA isolation and tissues samples were collected at day 14 or day 28 for assessment of culture positivity. Spirochetes could be recovered from 24-h skin biopsies collected from the site of inoculation from all four (100\%) of the B. burgdorferi B515-infected mice and from at least one additional tissue from each of these mice. Interestingly, although 24-h skin biopsies from $75 \%(3 / 4)$ of B331-infected mice were culture positive, spirochetes could not be recovered from any of the tissues from these mice. As expected, neither the 24-h skin biopsies nor the 14 or 28 day tissues collected from B31-4-inoculated mice were culture positive (Table 5). This indicates that inoculation with strain B331 resulted in transient infection at the injection site, but these spirochetes could not establish infection at distal tissue sites.

RNA was isolated from skin biopsies of five mice that were either mock-infected or inoculated with B. burgdorferi strain B515. These RNAs were separately pooled and used as templates for RT-PCR using the $\mathrm{RT}^{2}$ Profiler PCR Array PAMM-016: Mouse Interferon $\alpha, \beta$ Response kit (SABiosciences). This kit profiles the expression of 84 genes involved in the IFN- $\alpha$ and IFN- $\beta$ immune response, including signaling molecules, IFN-responsive genes, and genes associated with interferon resistance. Fifteen genes were induced $>2$-fold in B. burgdorferi B515-infected mouse skin relative to the mediuminoculated control group (Fig. 3). These genes included Ifit3 (15.7-fold), Ifit1 (4.3-fold), Cxcl10 (3.4-fold), Irf7 (3.3-fold), Gbp1 (2.6-fold), and Stat2 (2.3-fold).

Based on these PCR array results, differential induction of type I IFNs and selected IFN-responsive genes by B. burgdorferi was further evaluated by real-time RTPCR analysis of RNA isolated from 24-h skin biopsies collected from individual animals. RNA was obtained from all nine of the mice in each of the B. burgdorferi B515-infected and control groups, and from seven 
Table 3 Transcripts significantly induced in mouse blood in response to B. burgdorferi

\begin{tabular}{|c|c|c|c|c|c|}
\hline Unigene & Gene symbol & Gene title & Gene ontology & $\begin{array}{l}\mathrm{FC}^{\mathrm{a}} \\
\mathrm{B} 515\end{array}$ & $\begin{array}{l}\mathrm{FC}^{\mathrm{a}} \\
\mathrm{B} 331 \\
\end{array}$ \\
\hline \multicolumn{6}{|c|}{ Transcripts induced by B. burgdorferi B515 } \\
\hline Mm. 387173 & Chi3l3 & chitinase 3-like 3 & Inflammatory response & 9.14 & 1.17 \\
\hline Mm.9537 & Len2 & lipocalin 2 & Response to virus & 7.25 & -1.43 \\
\hline Mm.236225 & $\mathrm{Ngp}$ & neutrophil granule protein & Defense response to bacterium & 5.64 & -1.20 \\
\hline Mm.16415 & Mmp8 & matrix metallopeptidase 8 & Proteolysis & 5.21 & 1.01 \\
\hline \multirow[t]{2}{*}{ Mm.1349 } & $\| 1 \mathrm{r} 2$ & Interleukin 1 receptor, type II & Lipid metabolic process & 4.78 & -1.02 \\
\hline & lghg & Immunoglobulin heavy chain (gamma polypeptide) & & 4.23 & -1.08 \\
\hline Mm.158700 & Vcan & versican & Cell adhesion, heart development & 4.10 & 1.20 \\
\hline Mm.248327 & Clec4e & C-type lectin domain family 4 , member e & Immune response & 4.03 & 1.11 \\
\hline Mm.3834 & Camp & cathelicidin antimicrobial protein & Defense response to bacterium & 3.96 & -1.09 \\
\hline Mm.274927 & Cor1 & chemokine $(\mathrm{C}-\mathrm{C})$ receptor 1 & Inflammatory response & 3.68 & -0.05 \\
\hline Mm.24208 & ॥13ra1 & interleukin 13 receptor, alpha 1 & Cytokine-mediated signaling pathway & 3.63 & 1.15 \\
\hline Mm.477887 & Fpr2 & formyl peptide receptor 2 & G-protein coupled receptor signaling & 3.62 & -1.35 \\
\hline Mm.282359 & Ltf & lactotransferrin & Iron ion transport, homeostasis & 3.60 & -1.15 \\
\hline Mm.248360 & Anxa1 & annexin A1 & Leukocyte homeostasis & 3.45 & -1.26 \\
\hline Mm.9277 & Pla2g7 & phospholipase A2, group VII & Inflammatory response & 3.41 & 1.14 \\
\hline Mm.882 & $\| 1 \mathrm{rn}$ & interleukin 1 receptor antagonist & Negative regulation of cytokine-mediated signaling & 3.30 & 1.25 \\
\hline Mm.87596 & Tlr2 & toll-like receptor 2 & Pattern recognition receptor signaling pathway & 3.01 & -1.12 \\
\hline Mm.276440 & Ifitm6 & interferon induced transmembrane protein 6 & Response to biotic stimulus & 3.00 & -1.30 \\
\hline Mm.143718 & Mefv & Mediterranean fever & Inflammatory response & 2.93 & 1.09 \\
\hline Mm.19131 & $\mathrm{C} 3$ & complement component 3 & Inflammatory response, innate & 2.91 & -1.04 \\
\hline Mm.486 & Lamp2 & lysosomal-associated membrane protein 2 & & 2.89 & -1.09 \\
\hline Mm.336203 & $\operatorname{Tlr} 13$ & toll-like receptor 13 & Inflammatory response, signal Transduction & 2.72 & -1.22 \\
\hline Mm.3460 & Cd14 & CD14 antigen & Response to molecule of bacterial origin & 2.60 & -1.44 \\
\hline Mm.170515 & Nfkbia & $\begin{array}{l}\text { nuclear factor of kappa light polypeptide gene } \\
\text { enhancer in B cells inhibitor, alpha }\end{array}$ & Protein import into nucleus, Translocation & 2.55 & -1.29 \\
\hline Mm.47384 & Clec4a2 & C-type lectin domain family 4, member a2 & Immune response & 2.48 & 1.10 \\
\hline Mm.379266 & Ifitm2 & interferon induced transmembrane protein 2 & Response to biotic stimulus & 2.41 & -1.22 \\
\hline \multicolumn{6}{|c|}{ Transcript induced by B. burgdorferi B331 } \\
\hline Mm247642 & Arap3 & $\begin{array}{l}\text { ArfGAP with RhoGAP domain, ankyrin repeat } \\
\text { and PH domain }\end{array}$ & Signal transduction & 1.71 & 2.02 \\
\hline
\end{tabular}

${ }^{\mathrm{a}} \mathrm{FC}=$ fold change

animals each in the groups that had been infected with B. burgdorferi strains B31-4 and B331. Transcript levels were assessed for genes encoding murine IFN- $\beta$ $(I f n b)$ and the IFN-responsive genes Cxcl10, MxI, Irf3, Irf7, Gbp1, Stat2, Ifit1, and Ifit3. With the exception of Irf3, the mean fold-change values for all genes assessed were found to be significantly elevated in the skin of B. burgdorferi B515-infected mice relative to the medium-inoculated control group: $M x 1$ (9.5-fold), Ifnb (4.4-fold), Cxcl10 (8.0-fold), Irf7 (8.1-fold), Gbp1 (16.0-fold), Stat2 (6.8-fold), Ifit1 (18.8-fold), and Ifit3 (16.2-fold) (Fig. 4). In contrast, none of the genes assessed was found to be significantly induced or repressed relative to the controls in the mice inoculated with either B. burgdorferi strains B31-4 or B331. All genes except Ifit3 were significantly induced in B. burgdorferi B515-infected mice relative to B. burgdorferi B31-4-inoculated mice $(P<0.01)$. In addition, transcript levels for Cxcl10, Irf3, Irf7, Gbp1, Stat2, and Ifit1 were also significantly higher in skin at the inoculation site of mice infected with $B$. burgdorferi strain B515 as compared to animals infected with B. burgdorferi strain B331 $(P<0.05)$. These results demonstrate that only the $B$. burgdorferi strain capable of causing disseminated infection induces significant expression of type I IFN-related genes in mouse skin during early infection, in contrast to strains that do not disseminate. 
Table 4 Transcripts significantly repressed in mouse blood in response to B. burgdorferi

\begin{tabular}{|c|c|c|c|c|c|}
\hline Unigene & Gene symbol & Gene title & Gene ontology & $\begin{array}{l}\mathrm{FC}^{\mathrm{a}} \\
\mathrm{B} 515\end{array}$ & $\begin{array}{l}\mathrm{FC} C^{\mathrm{a}} \\
\mathrm{B} 331\end{array}$ \\
\hline \multicolumn{6}{|c|}{ Transcripts uniquely repressed by B. burgdorferi B515 } \\
\hline \multirow[t]{2}{*}{ Mm.1233 } & Fcer2a & Fc receptor, IgE, low affinity II, alpha polypeptide & $\begin{array}{l}\text { Positive regulation of humoral Immune response } \\
\text { mediated by circulating immunoglobulin }\end{array}$ & -3.34 & -1.42 \\
\hline & Ighv14-2 & immunoglobulin heavy variable $14-2$ & & -2.59 & -1.65 \\
\hline Mm.431426 & Bach2 & BTB and CNC homology 2 & Regulation of transcription, DNA-dependent & -2.42 & -1.80 \\
\hline Mm.476307 & Zfp799 & zinc finger protein & Regulation of transcription, DNA-dependent & -2.40 & -1.39 \\
\hline Mm.126193 & Tnik & TRAF2 and NCK interacting kinase & Protein phosphorylation & -2.39 & -1.40 \\
\hline Mm.439662 & Ebf1 & early B cell factor & Transcription, DNA-dependent & -2.30 & -1.28 \\
\hline Mm.486382 & Gm8369 & predicted gene 8369 & & -2.34 & -1.90 \\
\hline \multirow[t]{2}{*}{ Mm.482376 } & $4833423 F 13$ & RIKEN cDNA $4833423 F 13$ gene & & -2.33 & -1.31 \\
\hline & Rik & & & & \\
\hline Mm.441077 & BC002059 & cDNA sequence BC002059 & & -2.33 & -1.65 \\
\hline Mm.1850 & Fcrla & Fc receptor-like $A$ & Cell differentiation & -2.21 & -1.15 \\
\hline Mm.3411 & Orc2 & origin recognition complex, subunit 2 & DNA replication & -2.06 & -1.73 \\
\hline \multicolumn{6}{|c|}{ Transcripts repressed by B. burgdorferi B515 and B331 } \\
\hline Mm.271744 & Pfn2 & profilin 2 & Cytoskeleton organization & -3.14 & -2.94 \\
\hline \multirow[t]{2}{*}{ Mm.240047 } & Tnfrsf13c & tumor necrosis factor receptor & B-cell homeostasis & -2.10 & -2.16 \\
\hline & & superfamily, member $13 \mathrm{c}$ & & & \\
\hline \multicolumn{6}{|c|}{ Transcripts uniquely repressed by B. burgdorferi B331 } \\
\hline Mm.41979 & Mcpt8 & mast cell protease 8 & Proteolysis & -1.52 & -2.60 \\
\hline Mm.273270 & Cbll1 & Casitas B-lineage lymphoma-like 1 & Negative regulation of cell adhesion & -1.49 & -2.30 \\
\hline
\end{tabular}

${ }^{\mathrm{a}} \mathrm{FC}=$ fold change

\section{Discussion}

In this study we utilized host transcriptional profiling to identify alterations in gene expression that occur following intradermal inoculation of B. burgdorferi in a murine infection model. For a strain of $B$. burgdorferi that causes disseminated infection, a number of IFN-inducible genes were expressed both during acute localized infection at the inoculation site in skin and in blood collected 14 days after infection. This finding is consistent with numerous studies demonstrating an association between the induction of IFNs and Lyme disease pathogenesis. In human patients, significantly higher expression of serum IFN- $\alpha$ protein is associated with disseminated infection, as defined by the presence of multiple EM skin lesions as compared to patients with a single EM [4]. Transcripts for IFN- $\beta$ are induced in human monocytes and PBMCs during co-culture with $B$. burgdorferi $[35,36]$. Recently, we demonstrated that $B$. burgdorferi clinical isolates which are more frequently associated with disseminated infection in mice and humans induce significantly higher levels of IFN- $\alpha$ protein in human PBMCs as compared with isolates that are less likely to disseminate [23]. The current results extend the latter findings by identifying a correlation between $B$. burgdorferi dissemination and the induction of a type I IFN response in mice.

Table 5 Culture of B. burgdorferi from tissues of mice infected with strains B515, B331 or B31-4

\begin{tabular}{|c|c|c|c|c|c|c|}
\hline \multicolumn{7}{|c|}{ Number of samples with positive cultures/number tested (\%) } \\
\hline & \multirow{2}{*}{$\begin{array}{l}\text { Day } 1 \\
\text { Skin }^{a}\end{array}$} & \multirow{2}{*}{$\begin{array}{l}\text { Day } 14 \\
\text { Ear }\end{array}$} & \multicolumn{4}{|l|}{ Day 28} \\
\hline & & & $\overline{\text { Ear }}$ & Skin $^{a}$ & Bladder & Joint \\
\hline B31-4 & $0 / 4(0)$ & $0 / 9(0)$ & $0 / 9(0)$ & $0 / 9(0)$ & $0 / 9(0)$ & $0 / 9(0)$ \\
\hline B331 & $3 / 4(75.0)$ & $0 / 9(0)$ & $0 / 9(0)$ & $0 / 9(0)$ & $0 / 9(0)$ & $0 / 9(0)$ \\
\hline $\mathrm{B} 515^{\mathrm{b}}$ & $4 / 4(100.0)$ & $5 / 6(83.3)$ & $5 / 6(83.3)$ & $3 / 6(50.0)$ & $5 / 6(83.3)$ & $5 / 6(83.3)$ \\
\hline
\end{tabular}

${ }^{\text {a }}$ Skin biopsy was collected from the inoculation site

${ }^{\mathrm{b}}$ Three mice in the B515-infected group died of causes unrelated to the infection 


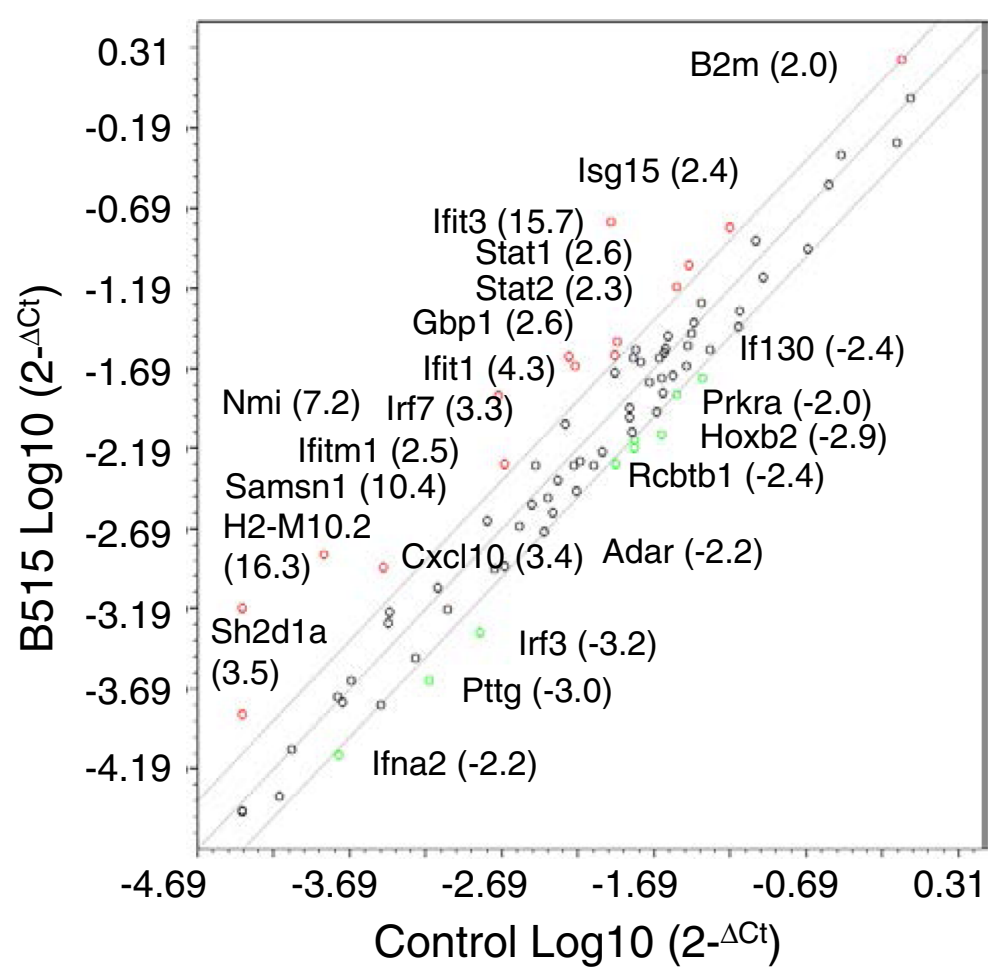

Fig. 3 Expression profiling of type I IFN-related genes in B515-infected mouse skin. Skin biopsies were collected from the site of inoculation $24 \mathrm{~h}$ after infection of mice with $1 \times 10^{4} \mathrm{~B}$. burgdorferi B515 spirochetes or with medium only (Control). Equivalent amounts of RNA from five animals per experimental group were separately pooled and used as a template for RT-PCR using the RT ${ }^{2}$ Profiler PCR Array PAMM-016: Mouse Interferon a, $\beta$ Response kit. Gene symbols are used to designate transcripts that were found to be changed at least two-fold in B515-infected skin relative to skin from controls. Fold change values are indicated in parentheses

Factors other than spirochete density appear to be critical for the induction of an IFN-responsive gene expression profile. Although viable spirochetes of B. burgdorferi strain B331 could be cultured from 24-h skin biopsies, expression for many of the IFN-responsive genes was significantly lower than that induced by an equivalent inoculum of B. burgdorferi B515 (Fig. 4). This result indicates that the magnitude of IFNresponsive gene expression is not only dependent on the presence of live spirochetes, but may also be an intrinsic genomic property of the $B$. burgdorferi isolate. Since quantitative assessment of spirochete burden by qPCR was not performed, no comparison can be made of the relative numbers of spirochetes present in the skin $24 \mathrm{~h}$ after infection. While this is a limitation of the current study, the major goal was to assess a correlation between expression of type I IFN-related genes and the potential for dissemination, which requires viable spirochetes; qPCR detects DNA from both live and dead spirochetes [37]. Moreover, several recent studies have found that spirochete DNA present in infected mouse skin is close to the limit of detection by qPCR prior to 72 or $96 \mathrm{~h}$ following inoculation, even when using DNA extracted from a much larger quantity of skin than was collected in this study [38, 39].

The results demonstrate that a $B$. burgdorferi strain that causes disseminated infection induces the expression of IFN-responsive genes in the skin and blood of infected animals. Previous studies had shown that IFN-responsive gene expression is a crucial factor in the development of Lyme arthritis in $\mathrm{C} 3 \mathrm{H}$ mice [26]. The current findings indicate that these gene products might have additional roles during earlier stages of infection. Interestingly, despite the induction of IFN-responsive gene transcripts by $B$. burgdorferi B515 in blood, transcripts for the interferons themselves were not detected by gene array analysis. This could be due to the fact that dendritic cells, the classic type I IFN-producing cell type, account for a very small percentage of the cellular components of blood relative to the number of cells that are capable of expressing IFN-responsive genes. Alternatively, as the presence of IFN transcripts in the blood was not assessed by RT-PCR, the possibility that IFN transcript levels were below the threshold of detection by gene array cannot be excluded. It should be noted that a gene array analysis of human dermal fibroblasts 


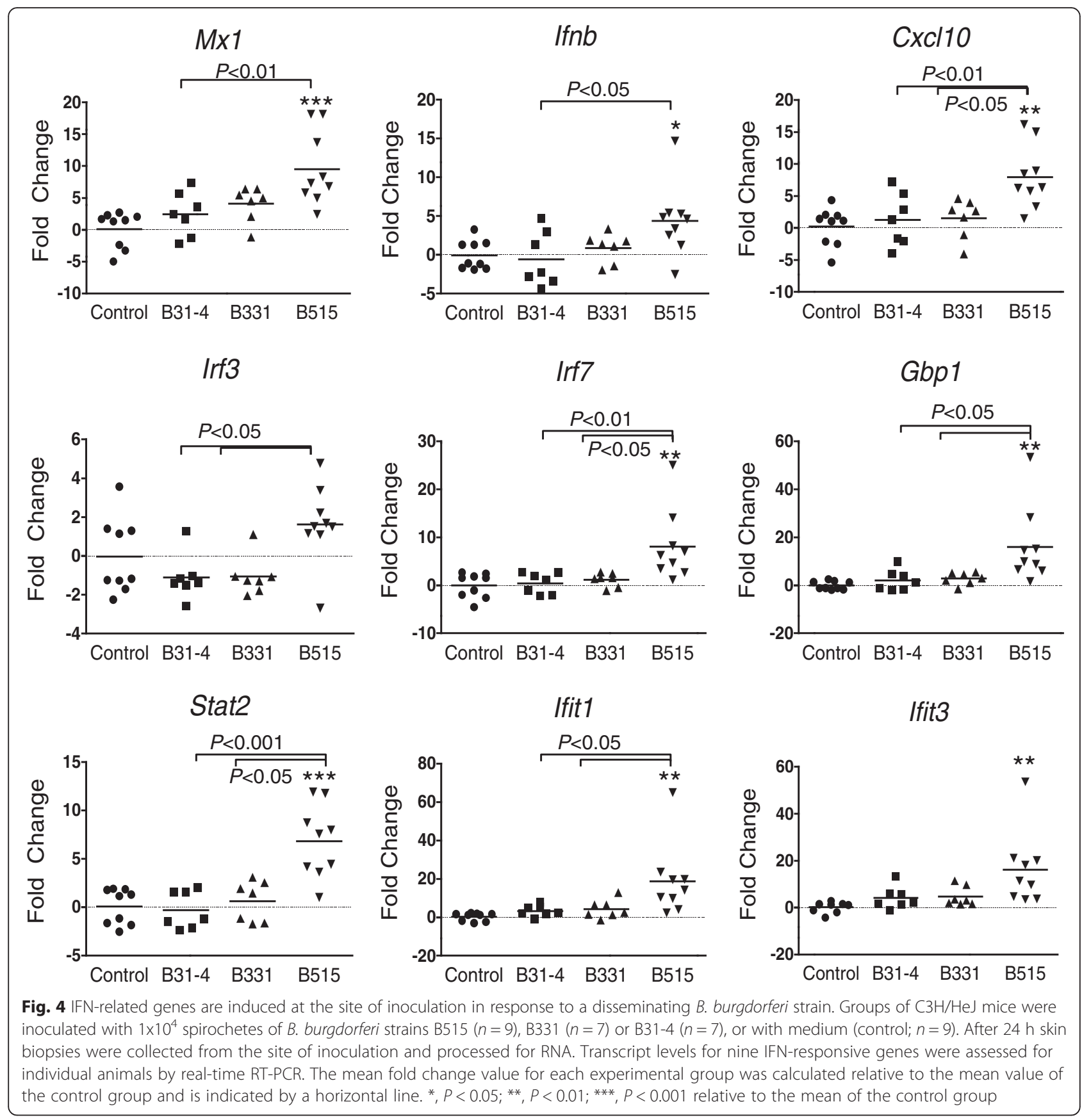

exposed to three different strains of B. burgdorferi showed induction of the IFN-responsive gene transcripts CXCL10, IRF1, STAT1, STAT2, OAS2, and IFIH1, but no induction of any IFN [40]. In addition, IFNs were not detectable by gene array analysis in the ankle tissue of $B$. burgdorferi-infected mice which developed severe arthritis concomitant with the expression of numerous IFN-responsive genes [25].

In addition to IFN-related transcripts, the transcripts that were most highly induced by $B$. burgdorferi B515 in mouse blood included a cluster of genes with defined roles in antimicrobial defense, remodeling of the extracellular matrix, dermal inflammatory conditions, and dendritic cell functions, particularly in skin (Table 3). Camp, an antimicrobial peptide with multiple functions in innate immunity of the skin and other epithelial barriers, is exploited by Staphylococcus aureus to promote bacterial dissemination and the establishment of invasive infection [41]. Formylpeptide receptor 2 (Fpr2), the receptor for Camp [42], was also induced by B. burgdorferi B515 (Table 3). Murine chitinase 3 -like protein 3 (Chi3L3) is a 
substrate for several matrix metalloproteases, including MMP-9, and is upregulated in the EM skin lesions of patients with acute Lyme disease [43]. Versican (Vcan) mediates extracellular matrix remodeling by promoting the interaction of pro-MMP-9 with gelatin and collagen [44].

The observation that B. burgdorferi $\mathrm{B} 515$ induced the expression of IFN-related genes in blood at 14 days post-inoculation suggested that such a response might occur at the initial infection site. Indeed, skin biopsies collected $24 \mathrm{~h}$ after inoculation of mice with $B$. burgdorferi strain B515, but not with B. burgdorferi strains B331 or B31-4, showed induction of a number of IFNresponsive genes. These same genes were among those induced in human PBMCs that had been exposed ex vivo to B. burgdorferi B515 [17, 23]. The presence of an IFN-responsive gene profile in mouse skin biopsies leads to the question of the identity of the inducing cytokine, as many IFN-responsive genes can be induced by more than one class of IFN. In the current study, transcript levels for IFN- $\beta$ were significantly induced, but transcription of IFN- $\gamma$ was not assessed. B. burgdorferi is a potent inducer of IFN- $\gamma$, and both type I IFN and IFN- $\gamma$ are produced in the EM lesion blister fluids of human Lyme disease patients [4]. In B. burgdorferistimulated human PBMCs, transcript levels for IFN- $\gamma$ were observed to be at least 10-fold higher than levels for either IFN- $\alpha$ or IFN- $\beta$ [36]. While we cannot exclude the possibility that the IFN-responsive gene expression profile observed in 24-h skin biopsies from mice infected with $B$. burgdorferi strain B515 is elicited by contributions from both IFN- $\gamma$ and IFN- $\beta$, it should be noted that all strains, regardless of genotype, were equally effective at inducing high levels of IFN- $\gamma$ protein, while only strains of the RST1 genotype elicited significantly higher production of IFN- $\alpha$ [23].

A limitation of the present study is that responses to only three $B$. burgdorferi isolates were studied. $B$. burgdorferi strain $\mathrm{B} 515$ is an RST1/OspC type A genotype; numerous studies have revealed that strains belonging to this genotype are genetically homogeneous, in contrast to RST2 and RST3 genotypes [4548]. Moreover, B. burgdorferi RST1 isolates have been shown to induce significantly higher levels of IFN- $\alpha$, and possess a greater capacity to cause invasive infection, than do RST3 isolates [23, 24]. It is therefore reasonable to predict that the findings of the present study with regard to induction of IFN-responsive genes in a genotype-specific manner would pertain to other B. burgdorferi isolates.

In the present study, mice were infected by needle inoculation. This procedure allows for the standardization of parameters, such as the number of spirochetes in the inoculum and the time of inoculation, and has been routinely employed to investigate the early kinetics of B. burgdorferi infection [38, 39]. A limitation of this approach is that it does not fully recapitulate physiological infection by tick bite. Borrelia afzelii-induced IFN signaling by mouse dendritic cells was suppressed by Ixodes ricinus tick saliva in vitro, although the amount of Ifnb transcript was not affected [49]. Tick salivary gland extracts were found to have a cytotoxic effect on human dermal fibroblasts in vitro [40], whereas tick salivary gland lysates enhanced spirochete load in tissues of infected mice [50]. In view of these findings, it would be of interest in future studies to address the effects of tick-related factors on the expression of IFN-responsive genes in the skin by comparing the results of needle inoculation with those obtained following spirochete inoculation via tick bite.

Induction of multiple IFN-responsive genes has been observed in a range of skin pathologies, including autoimmune skin inflammation [51], wound healing following skin injury [52], and the development of adult and juvenile dermatomyositis [53]. While predominantly host protective during viral infections, type I IFNs have also been shown to promote the pathogenesis of several intracellular and extracellular bacteria, including species that invade epithelial barriers [54-58]. One proposed mechanism for type I IFN-mediated bacterial pathogenesis occurs via suppression of myeloid cells [59]. Indeed, we have demonstrated that B. burgdorferi B31-A3, an RST1 strain that readily disseminates in mice, induces significantly higher expression of both IFN- $\alpha$ [23] and indoleamine 2,3-dioxygenase [60], an enzyme with immunomodulatory functions in human myeloid and plasmacytoid dendritic cells [61], as compared to a mutant strain that is severely attenuated for infectivity. Expression of indoleamine 2,3-dioxygenase was found to be driven by the concerted actions of both $B$. burgdorferiinduced IFN- $\gamma$ and type I IFN [60]. The expression of type I IFN and IFN-responsive genes in mouse skin may therefore comprise a fingerprint of activated suppressor dendritic cells, which potentially could be manipulated by the spirochete in order to promote pathogenesis.

\section{Conclusions}

Host transcriptional profiling was utilized to identify transcriptional alterations in blood and skin during B. burgdorferi infection in a murine infection model. The results suggest a number of potential hostprotective and pathogen-promoting strategies that include the expression of antimicrobial peptides and molecules involved in extracellular matrix remodeling. Most notably, a strong association between early expression of Ifn $b$ and IFN-responsive genes at the site of inoculation, and the capacity of certain B. burgdorferi 
strains to invade the bloodstream was observed. The findings imply that type I IFNs may play a pivotal role in the early stages of Lyme disease pathogenesis and suggests a potential immune evasion strategy that may be exploited by certain $B$. burgdorferi strains to facilitate dissemination.

\section{Methods}

\section{$B$. burgdorferi strains and clinical isolates}

B. burgdorferi isolates B515 (RST1) and B331 (RST3A) were obtained from skin biopsies taken from the EM skin lesions of Lyme disease patients enrolled in a prior study at the Lyme Disease Diagnostic Center at New York Medical College, Valhalla, NY and have been previously described [13]. B. burgdorferi strain B31-4, a high passage derivative of $B$. burgdorferi strain B31 (RST1) that lacks all linear plasmids and consequently is unable to disseminate in mice or induce IFN- $\alpha$ by human peripheral blood mononuclear cells, has been previously described [23, 34].

B. burgdorferi strains were grown at $37^{\circ} \mathrm{C}$ in modified Barbour-Stoenner-Kelly (BSK-S) medium [62]. Cultures were maintained at $37^{\circ} \mathrm{C}$ until spirochetes reached the mid- to late-log phase of growth $\left(4 \times 10^{7}\right.$ to $8 \times 10^{7} / \mathrm{ml}$ ). In the experiment performed to assess induction of IFN transcripts in skin, B. burgdorferi cultures were initially grown as above. However, to simulate the temperature changes that occur during transmission from tick to mammal and that may enhance the expression of certain virulence factors [63, 64], spirochetes were subcultured and grown at $25^{\circ} \mathrm{C}$ to the mid-log phase of growth, then diluted to $1 \times$ $10^{6}$ spirochetes $/ \mathrm{ml}$ and grown at $37{ }^{\circ} \mathrm{C}$ until cultures once again reached mid- to late-log phase of growth [65]. Spirochetes were enumerated and assessed for motility using dark-field microscopy [66].

\section{Mouse infection}

All animal experimentation was conducted in strict accordance with the recommendations in the Guide for the Care and Use of Laboratory Animals of the National Institutes of Health. The protocols were approved by the Institutional Animal Care and Use Committee of New York Medical College.

$\mathrm{C} 3 \mathrm{H} / \mathrm{HeJ}$ mice were employed throughout, as this strain is susceptible to the development of Lyme arthritis and produces a type I IFN response to B. burgdorferi infection $[12,13,26]$. For assessment of the host transcriptional response in whole blood, specific pathogen-free 6-8-week-old male or female $\mathrm{C} 3 \mathrm{H} / \mathrm{HeJ}$ mice were randomly divided into groups of 15 . Anesthetized mice were needle inoculated by intradermal injection on the shaven back with $1 \times 10^{4}$ spirochetes of B515 or B331 in $0.1 \mathrm{ml}$ BSK-S. Control animals were inoculated with $0.1 \mathrm{~mL}$ BSK-S alone. Whole blood samples were collected from each mouse at day 0 and day 14. Ear samples were obtained at day 14, and blood, ear, joint and urinary bladder tissues were collected following euthanization on day 28.

To assess infectivity, blood and tissue samples were cultured and serology was performed. Three to five drops of whole blood were added directly to $4 \mathrm{ml}$ of BSK-S medium. Tissue samples ( 10-20 mg) were placed in $70 \%$ ethanol for $3 \mathrm{~min}$ and transferred to $4.5 \mathrm{~mL}$ of BSK-S containing fosfomycin $(20 \mu \mathrm{g} / \mathrm{mL})$, rifampicin $(50 \mu \mathrm{g} / \mathrm{mL})$, and amphotericin $(2.5 \mu \mathrm{g} / \mathrm{mL})$ (Sigma-Aldrich, all) to inhibit the growth of commensal bacteria [67]. Cultures were maintained at $37{ }^{\circ} \mathrm{C}$ for 4 weeks and examined weekly for the presence of spirochetes. Serum collected at days 14 and 28 was probed for the presence of anti-Borrelia antibodies using strainspecific whole-cell lysates [68]. Tibiotarsal joints were measured on days 7, 14, 21 and 28 using a digital metric caliper through the thickest anteroposterior diameter of the ankle.

In order to assess the type I IFN response in mouse skin during early infection, groups of nine $\mathrm{C} 3 \mathrm{H} / \mathrm{HeJ}$ mice were needle inoculated as described above with $1 \times 10^{4}$ spirochetes of B. burgdorferi strains B515 or B331. As a control, a group of mice was infected with $1 \times 10^{4}$ spirochetes of B. burgdorferi strain B31-4. This mutant derivative of B. burgdorferi strain B31 (RST1, OspC A) lacks all linear plasmids, is unable to disseminate in mice [34], and is unable to elicit IFN- $\alpha$ secretion by human immune cells [23]. Skin biopsies ( $2 \mathrm{~mm}$ diameter) were collected from the injection site $24 \mathrm{~h}$ after inoculation. The skin biopsy was cut in half; one half was snap frozen and stored at $-80^{\circ}$ $\mathrm{C}$ for RNA isolation and the other half was washed with $70 \%$ ethanol, transferred to $5 \mathrm{~mL}$ of BSK-S containing the antibiotics described above and incubated. To assess spirochetal dissemination, ear, joint, and urinary bladder tissues, and skin collected from the site of inoculation, were collected following euthanization at day 28 and assessed for the growth of spirochetes as described above.

\section{RNA isolation from murine skin biopsies}

For real time RT-PCR analysis of individual IFNresponsive genes, skin samples were homogenized in a glass tissue homogenizer containing $300 \mu \mathrm{L}$ of denaturation solution from the Ambion ToTALLY RNA isolation kit (Life Technologies, Grand Island, NY). Mouse hair was removed from the samples by centrifugation at $3000 \mathrm{rpm}$ for $3 \mathrm{~min}$ and RNA was isolated from skin homogenates using the Ambion ToTALLY RNA kit (Life Technologies). Contaminating genomic DNA was removed by oncolumn DNase I treatment using the Qiagen RNeasy Mini 
Kit (Qiagen, Valencia, CA). Total RNA was eluted in 30 $\mu \mathrm{L}$ of RNase/DNase-free water and quantitated by spectrophotometry (BioPhotometer, Eppendorf, Hauppauge, NY). RNA samples were stored at $-80^{\circ} \mathrm{C}$ after the addition of $0.8 \mu \mathrm{L}$ (32 U) of RNasin (Promega, Madison, WI).

\section{Microarray hybridization and data analysis}

Whole blood was collected from mice at 14 days postinoculation. In order to ensure a sufficient RNA yield, samples from subgroups of three mice were pooled, resulting in five biological replicates per experimental group. RNA was isolated from whole blood using the Gentra Purescript Blood RNA Isolation kit (Qiagen) and stored at $-80^{\circ} \mathrm{C}$ in the presence of RNase inhibitors until processing. RNA quality was assessed using a bioanalyzer (Agilent Technologies, Santa Clara, CA) and by spectrophotometric analysis. cDNA was generated by amplification of the RNA using the Ovation RNA Amplification System V2 (NuGEN Technologies, Inc., San Carlos, CA). cDNA was fragmented to 50-100 bp, labelled with biotin, and hybridized to the Mouse 430_2 GeneChip high-density oligonucleotide array containing 39,000 mouse probe sets representing 34,000 genes (Affymetrix, Santa Clara, CA). Hybridization, staining and washing of all arrays was performed in an Affymetrix fluidics module. The dataset supporting the results of this article is available in the ArrayExpress database, accession number E-MTAB-3325 (http:// www.ebi.ac.uk/arrayexpress).

Microarray data were analyzed using GeneSpring GX12.0 software (Agilent Technologies). Raw expression values were normalized by robust multi-array averaging, filtered to include only those probe sets with intensity values above the $20^{\text {th }}$ percentile, and baseline transformed to the median of the control samples. Statistical significance was determined by use of a one-way ANOVA with Welch correction for unequal variances. Criteria for differentially expressed transcripts included a $P$-value of $<0.05$ and at least a two-fold change relative to the control group. Differentially expressed genes were subjected to hierarchical clustering based on both transcripts and experimental condition.

\section{PCR array}

Total RNA was isolated from skin biopsies collected from the site of inoculation in B. burgdorferi B515infected and medium-inoculated control mice, as described above. For each experimental group, RNA from five animals was pooled, and a total of $1 \mu \mathrm{g}$ pooled RNA was used as a template for first-strand cDNA synthesis. IFN-associated gene transcription was measured using the SABiosciences $\mathrm{RT}^{2}$ Profiler PCR Array PAMM-016: Mouse Interferon $\alpha, \beta$ Response kit (Qiagen), according to the manufacturer's instructions.

\section{Real-time quantitative RT-PCR}

Real-time quantitative RT-PCR was used to validate blood gene array data and to measure transcription of type I IFN-responsive genes in mouse skin biopsies. cDNA was synthesized from $1 \mu \mathrm{g}$ of total RNA in $20-\mu \mathrm{l}$ reaction mixtures containing $250 \mu \mathrm{M}$ of each dNTP, $0.5 \mu \mathrm{g}$ random primers, $5 \mathrm{U}$ AMV Reverse Transcriptase (RT) enzyme, $10 \mathrm{U}$ RNase inhibitor and $4 \mu \mathrm{L}$ of $5 \mathrm{X}$ RT buffer (all from Promega). Reactions were performed at $42{ }^{\circ} \mathrm{C}$ for 75 min and terminated by heating at $94{ }^{\circ} \mathrm{C}$ for 5 min. cDNA was stored at $-20^{\circ} \mathrm{C}$ until use.

PCR was performed using the following TaqMan Assays-on-Demand (Applied Biosystems, Grand Island, NY): Camp (cathelicidin antimicrobial peptide; Mm00438285_m1), Ccr7 (chemokine (C-C motif) receptor 7; Mm01301785_m1), Cxcl10 (chemokine (C-X-C motif) ligand 10; Mm00445235_m1), Gbp1 (guanylate binding protein 1; Mm00657086_m1), Ifit1 (interferoninduced protein with tetratricopeptide repeats 1; Mm00515153_m1), Ifit3 (interferon-induced protein with tetratricopeptide repeats 3; Mm01704846_s1), Ifnb1 (interferon-beta; Mm00439552_s1), Irf3 (interferon regulatory factor 3; Mm00516779_m1), Irf7 (interferon regulatory factor 7; Mm00516788_m1), Mx1 (myxovirus (influenza virus) resistance 1; Mm00487796_m1), Ngp (neutrophil granule protein; Mm00476389_m1), Stat2 (signal transducer and activator of transcription 2; Mm00490880_m1), and Vcan (Cspg2) (versican; chondroitin sulfate proteoglycan 2; Mm00490179_m1). All assays were performed in duplicate in $25 \mu \mathrm{L}$ reaction mixtures containing TaqMan gene expression assay mix, FastStart universal probe master mix (Roche), and $2 \mu \mathrm{L}$ cDNA (diluted 1:2) using the ABI 7900HT SDS sequence detection system (Applied Biosystems), according to the manufacturer's instructions. As an internal control, the expression of murine $\beta$-actin was measured in duplicate for each sample using the TaqMan mouse endogenous control assay (Actb; Mm00607939_s1, Applied Biosystems). The $\Delta \Delta \mathrm{C}_{\mathrm{t}}$ relative quantitation method was used to calculate differential gene expression between groups [69].

\section{Statistical analysis}

Statistical significance of differences between the mean RT-PCR fold-change values of experimental groups was determined using a one-way ANOVA with TukeyKramer's post-hoc test (GraphPad Prism, version 5.03; GraphPad Software, San Diego, CA). A Fisher's exact test was performed to determine significant differences in the numbers of infected tissues.

Competing interests

The authors declare that they have no competing interests. 


\section{Authors' contributions}

MMP participated in the design of the study, performed mouse infection (skin), analyzed data, and drafted the manuscript. RI performed mouse infection (blood). ACL isolated RNA, performed RT-PCR, and participated in drafting the manuscript. ZS isolated RNA and performed RT-PCR. AB conducted gene array hybridization. IS participated in the design of the study and contributed to the preparation of the manuscript. All authors read and approved the final manuscript.

\section{Acknowledgments}

This work was supported by grant/cooperative agreement U01Cl000160 from the United States Centers for Disease Control and Prevention. Its contents are solely the responsibility of the authors and do not necessarily represent the official views of CDC. The authors gratefully acknowledge the technical assistance of Rene Devis.

\section{Author details}

'Department of Microbiology and Immunology, New York Medical College, Valhalla, New York, USA. ${ }^{2}$ Bionomics Research and Technology Center, Robert Wood Johnson-University of Medicine and Dentistry of New Jersey/Rutgers University, Piscataway, New Jersey, USA. ${ }^{3}$ Present Address: Nexcelom Bioscience LLC, Lawrence, Massachusetts, USA.

\section{Received: 21 September 2015 Accepted: 25 February 2016} Published online: 08 March 2016

\section{References}

1. Bacon RM, Kugeler KJ, Mead PS. Surveillance for Lyme disease-United States, 1992-2006. MMWR Surveill Summ. 2008;57:1-9.

2. Steere AC. Lyme disease. N Engl J Med. 2001;345:115-25.

3. Mullegger RR, McHugh G, Ruthazer R, Binder B, Kerl H, Steere AC. Differential expression of cytokine mRNA in skin specimens from patients with erythema migrans or acrodermatitis chronica atrophicans. J Invest Dermatol. 2000;115:1115-23.

4. Salazar JC, Pope CD, Sellati TJ, Feder Jr HM, Kiely TG, Dardick KR, et al. Coevolution of markers of innate and adaptive immunity in skin and peripheral blood of patients with erythema migrans. J Immunol. 2003;171:2660-70

5. Wormser GP, Dattwyler RJ, Shapiro ED, Halperin JJ, Steere AC, Klempner MS, et al. The clinical assessment, treatment, and prevention of lyme disease, human granulocytic anaplasmosis, and babesiosis: clinical practice guidelines by the Infectious Diseases Society of America. Clin Infect Dis. 2006:43:1089-134.

6. Stanek G, Wormser GP, Gray J, Strle F. Lyme borreliosis. Lancet. 2012;379:461-73.

7. Wang G, Liveris D, Mukherjee P, Jungnick S, Margos G, Schwartz I. Molecular Typing of Borrelia burgdorferi. Curr Protoc Microbiol. 2014;34:12C.

8. Seinost G, Dykhuizen DE, Dattwyler RJ, Golde WT, Dunn JJ, Wang IN, et al. Four clones of Borrelia burgdorferi sensu stricto cause invasive infection in humans. Infect Immun. 1999:67:3518-24.

9. Wormser GP, Liveris D, Nowakowski J, Nadelman RB, Cavaliere LF, McKenna $D$, et al. Association of specific subtypes of Borrelia burgdorferi with hematogenous dissemination in early Lyme disease. J Infect Dis. 1999;180:720-5

10. Jones KL, Glickstein $\amalg$, Damle N, Sikand VK, McHugh G, Steere AC. Borrelia burgdorferi genetic markers and disseminated disease in patients with early Lyme disease. J Clin Microbiol. 2006:44:4407-13.

11. Wormser GP, Brisson D, Liveris D, Hanincova K, Sandigursky S, Nowakowski J, et al. Borrelia burgdorferi genotype predicts the capacity for hematogenous dissemination during early Lyme disease. J Infect Dis. 2008;198:1358-64.

12. Wang G, Ojaimi C, lyer R, Saksenberg V, McClain SA, Wormser GP, et al. Impact of genotypic variation of Borrelia burgdorferi sensu stricto on kinetics of dissemination and severity of disease in $\mathrm{C} 3 \mathrm{H} / \mathrm{HeJ}$ mice. Infect Immun. 2001:69:4303-12

13. Wang G, Ojaimi C, Wu H, Saksenberg V, lyer R, Liveris D, et al. Disease severity in a murine model of lyme borreliosis is associated with the genotype of the infecting Borrelia burgdorferi sensu stricto strain. J Infect Dis. 2002;186:782-91.

14. Radolf JD, Arndt LL, Akins DR, Curetty LL, Levi ME, Shen Y, et al. Treponema pallidum and Borrelia burgdorferi lipoproteins and synthetic lipopeptides activate monocytes/macrophages. J Immunol. 1995;154:2866-77.
15. Miller JC, Maylor-Hagen H, Ma Y, Weis JH, Weis JJ. The Lyme disease spirochete Borrelia burgdorferi utilizes multiple ligands, including RNA, for interferon regulatory factor 3-dependent induction of type I interferonresponsive genes. Infect Immun. 2010;78:3144-53.

16. Cervantes JL, La Vake CJ, Weinerman B, Luu S, O'Connell C, Verardi PH, et al. Human TLR8 is activated upon recognition of Borrelia burgdorferi RNA in the phagosome of human monocytes. J Leukoc Biol. 2013;94:1231-41.

17. Love AC, Schwartz I, Petzke MM. Borrelia burgdorferi RNA induces type I and type III interferons via TLR7 and contributes to the production of NF-kappaB-dependent cytokines. Infect Immun. 2014;82:2405-16.

18. Zeidner N, Mbow ML, Dolan M, Massung R, Baca E, Piesman J. Effects of Ixodes scapularis and Borrelia burgdorferi on modulation of the host immune response: induction of a $\mathrm{TH} 2$ cytokine response in Lyme disease-susceptible $(\mathrm{C} 3 \mathrm{H} / \mathrm{HeJ})$ mice but not in disease-resistant (BALB/C) mice. Infect Immun. 1997:65:3100-6

19. Widhe $M$, Jarefors $S$, Ekerfelt $C$, Vrethem $M$, Bergstrom S, Forsberg $P$, et al. Borrelia-specific interferon-gamma and interleukin-4 secretion in cerebrospinal fluid and blood during Lyme borreliosis in humans: association with clinical outcome. J Infect Dis. 2004;189:1881-91.

20. Zeidner NS, Schneider BS, Rutherford JS, Dolan MC. Suppression of Th2 cytokines reduces tick-transmitted Borrelia burgdorferi load in mice. J Parasitol. 2008;94:767-9.

21. Sjowall J, Fryland L, Nordberg M, Sjogren F, Garpmo U, Jansson C, et al. Decreased Th1-type inflammatory cytokine expression in the skin is associated with persisting symptoms after treatment of erythema migrans. PLoS One. 2011:6:e18220.

22. Wang G, Petzke MM, lyer R, Wu H, Schwartz I. Pattern of proinflammatory cytokine induction in RAW264.7 mouse macrophages is identical for virulent and attenuated Borrelia burgdorferi. J Immunol. 2008;180:8306-15.

23. Krupna-Gaylord MA, Liveris D, Love AC, Wormser GP, Schwartz I, Petzke MM Induction of type I and type III interferons by Borrelia burgdorferi correlates with pathogenesis and requires linear plasmid 36. PLoS One. 2014;9:e100174.

24. Strle K, Jones KL, Drouin EE, Li X, Steere AC. Borrelia burgdorferi RST1 (OspC type A) genotype is associated with greater inflammation and more severe Lyme disease. Am J Pathol. 2011;178:2726-39.

25. Crandall H, Dunn DM, Ma Y, Wooten RM, Zachary JF, Weis JH, et al. Gene expression profiling reveals unique pathways associated with differential severity of lyme arthritis. J Immunol. 2006;177:7930-42.

26. Miller JC, Ma Y, Bian J, Sheehan KC, Zachary JF, Weis JH, et al. A critical role for type I IFN in arthritis development following Borrelia burgdorferi infection of mice. J Immunol. 2008:181:8492-503.

27. Massoud AH, Yona M, Xue D, Chouiali F, Alturaihi H, Ablona A, et al. Dendritic cell immunoreceptor: a novel receptor for intravenous immunoglobulin mediates induction of regulatory $T$ cells. J Allergy Clin Immunol. 2014:133:853-63.

28. Hidmark A, von Saint PA, Dalpke AH. Cutting edge: TLR13 is a receptor for bacterial RNA. J Immunol. 2012:189:2717-21.

29. Oldenburg M, Kruger A, Ferstl R, Kaufmann A, Nees G, Sigmund A, et al. TLR13 recognizes bacterial 23S rRNA devoid of erythromycin resistanceforming modification. Science. 2012;337:1111-5

30. Signorino G, Mohammadi N, Patane F, Buscetta M, Venza M, Venza I, et al, Role of TLR13 in innate immune recognition of group B streptococci. Infect Immun. 2014:82:5013-2.

31. Hirschfeld M, Kirschning CJ, Schwandner R, Wesche H, Weis JH, Wooten RM, et al. Cutting edge: inflammatory signaling by Borrelia burgdorferi lipoproteins is mediated by toll-like receptor 2. J Immunol. 1999;163:2382-6.

32. Lien E, Sellati TJ, Yoshimura A, Flo TH, Rawadi G, Finberg RW, et al. Toll-like receptor 2 functions as a pattern recognition receptor for diverse bacterial products. J Biol Chem. 1999;274:33419-25.

33. Sahay B, Patsey RL, Eggers CH, Salazar JC, Radolf JD, Sellati TJ. CD14 signaling restrains chronic inflammation through induction of p38-MAPK SOCS-dependent tolerance. PLoS Pathog. 2009;5:e1000687.

34. Sadziene A, Wilske B, Ferdows MS, Barbour AG. The cryptic ospC gene of Borrelia burgdorferi B31 is located on a circular plasmid. Infect Immun. 1993;61:2192-5

35. Salazar JC, Duhnam-Ems S, La VC, Cruz AR, Moore MW, Caimano MJ, et al. Activation of human monocytes by live Borrelia burgdorferi generates TLR2dependent and -independent responses which include induction of IFNbeta. PLoS Pathog. 2009;5:e1000444.

36. Petzke MM, Brooks A, Krupna MA, Mordue D, Schwartz I. Recognition of Borrelia burgdorferi, the Lyme disease spirochete, by TLR7 and TLR9 
induces a type I IFN response by human immune cells. J Immunol. 2009;183:5279-92.

37. Iyer R, Mukherjee P, Wang K, Simons J, Wormser GP, Schwartz I. Detection of Borrelia burgdorferi nucleic acids after antibiotic treatment does not confirm viability. J Clin Microbiol. 2013;51:857-62.

38. Lazarus JJ, McCarter AL, Neifer-Sadhwani K, Wooten RM. ELISA-based measurement of antibody responses and PCR-based detection profiles can distinguish between active infection and early clearance of Borrelia burgdorferi. Clin Dev Immunol. 2012;2012:138069.

39. Kern A, Schnell G, Bernard Q, Boeuf A, Jaulhac B, Collin E, et al. Heterogeneity of Borrelia burgdorferi sensu stricto population and its involvement in borrelia pathogenicity: Study on murine model with specific emphasis on the skin interface. PLoS One. 2015;10:e0133195.

40. Schramm F, Kern A, Barthel C, Nadaud S, Meyer N, Jaulhac B, et al. Microarray analyses of inflammation response of human dermal fibroblasts to different strains of Borrelia burgdorferi sensu stricto. PLoS One. 2012;7, e40046.

41. Braff MH, Jones AL, Skerrett SJ, Rubens CE. Staphylococcus aureus exploits cathelicidin antimicrobial peptides produced during early pneumonia to promote staphylokinase-dependent fibrinolysis. J Infect Dis. 2007;195:1365-72

42. Kurosaka K, Chen Q, Yarovinsky F, Oppenheim JJ, Yang D. Mouse cathelinrelated antimicrobial peptide chemoattracts leukocytes using formyl peptide receptor-like 1 /mouse formyl peptide receptor-like 2 as the receptor and acts as an immune adjuvant. J Immunol. 2005;174:6257-65.

43. Zhao Z, Chang H, Trevino RP, Whren K, Bhawan J, Klempner MS. Selective up-regulation of matrix metalloproteinase-9 expression in human erythema migrans skin lesions of acute lyme disease. J Infect Dis. 2003;188:1098-104.

44. Malla N, Berg E, Uhlin-Hansen L, Winberg JO. Interaction of pro-matrix metalloproteinase-9/proteoglycan heteromer with gelatin and collagen. J Biol Chem. 2008;283:13652-65.

45. Terekhova D, lyer R, Wormser GP, Schwartz I. Comparative genome hybridization reveals substantial variation among clinical isolates of Borrelia burgdorferi sensu stricto with different pathogenic properties. J Bacteriol. 2006;188:6124-34.

46. Hanincova K, Liveris D, Sandigursky S, Wormser GP, Schwartz I. Borrelia burgdorferi sensu stricto is clonal in patients with early Lyme borreliosis. Appl Environ Microbiol. 2008;74:5008-14.

47. Qiu WG, Bruno JF, McCaig WD, Xu Y, Livey I, Schriefer ME, et al. Wide distribution of a high-virulence Borrelia burgdorferi clone in Europe and North America. Emerg Infect Dis. 2008;14:1097-104.

48. Hanincova K, Mukherjee P, Ogden NH, Margos G, Wormser GP, Reed KD, et al. Multilocus sequence typing of Borrelia burgdorferi suggests existence of lineages with differential pathogenic properties in humans. PLoS One. 2013; 8:e73066.

49. Lieskovska J, Kopecky J. Tick saliva suppresses IFN signalling in dendritic cells upon Borrelia afzelii infection. Parasite Immunol. 2012;34:32-9.

50. Zeidner NS, Schneider BS, Nuncio MS, Gern L, Piesman J. Coinoculation of Borrelia spp. with tick salivary gland lysate enhances spirochete load in mice and is tick species-specific. J Parasitol. 2002;88:1276-8.

51. Guiducci C, Tripodo C, Gong M, Sangaletti S, Colombo MP, Coffman RL, et al. Autoimmune skin inflammation is dependent on plasmacytoid dendritic cell activation by nucleic acids via TLR7 and TLR9. J Exp Med. 2010;207:2931-42.

52. Gregorio J, Meller S, Conrad C, Di NA, Homey B, Lauerma A, et al. Plasmacytoid dendritic cells sense skin injury and promote wound healing through type I interferons. J Exp Med. 2010;207:2921-30.

53. Baechler EC, Bilgic H, Reed AM. Type I interferon pathway in adult and juvenile dermatomyositis. Arthritis Res Ther. 2011;13:249.

54. Qiu H, Fan Y, Joyee AG, Wang S, Han X, Bai H, et al. Type I IFNs enhance susceptibility to Chlamydia muridarum lung infection by enhancing apoptosis of local macrophages. J Immunol. 2008;181:2092-102.

55. Auerbuch V, Brockstedt DG, Meyer-Morse N, O'Riordan M, Portnoy DA. Mice lacking the type I interferon receptor are resistant to Listeria monocytogenes. J Exp Med. 2004;200:527-33.

56. Carrero JA, Calderon B, Unanue ER. Type I interferon sensitizes lymphocytes to apoptosis and reduces resistance to Listeria infection. J Exp Med. 2004;200:535-40.

57. Manca C, Tsenova L, Bergtold A, Freeman S, Tovey M, Musser JM, et al. Virulence of a Mycobacterium tuberculosis clinical isolate in mice is determined by failure to induce Th1 type immunity and is associated with induction of IFN-alpha /beta. Proc Natl Acad Sci U S A. 2001;98:5752-7.

58. Parker D, Planet PJ, Soong G, Narechania A, Prince A. Induction of type I interferon signaling determines the relative pathogenicity of Staphylococcus aureus strains. PLoS Pathog. 2014;10:e1003951.

59. Eshleman EM, Lenz LL. Type I interferons in bacterial infections: taming of myeloid cells and possible implications for autoimmunity. Front Immunol. 2014;5:431.

60. Love AC, Schwartz I, Petzke MM. Induction of indoleamine 2,3-dioxygenase by Borrelia burgdorferi in human immune cells correlates with pathogenic potential. J Leukoc Biol. 2015;97:379-90.

61. King NJ, Thomas SR. Molecules in focus: indoleamine 2,3-dioxygenase. Int J Biochem Cell Biol. 2007;39:2167-72.

62. Wang G, lyer R, Bittker S, Cooper D, Small J, Wormser GP, et al. Variations in Barbour-Stoenner-Kelly culture medium modulate infectivity and pathogenicity of Borrelia burgdorferi clinical isolates. Infect Immun. 2004;72:6702-6.

63. Stevenson B, Schwan TG, Rosa PA. Temperature-related differential expression of antigens in the Lyme disease spirochete. Borrelia burgdorferi. Infect Immun. 1995;63:4535-9.

64. Ojaimi C, Brooks C, Casjens S, Rosa P, Elias A, Barbour A, et al. Profiling of temperature-induced changes in Borrelia burgdorferi gene expression by using whole genome arrays. Infect Immun. 2003:71:1689-705.

65. Moore MW, Cruz AR, LaVake CJ, Marzo AL, Eggers CH, Salazar JC, et al. Phagocytosis of Borrelia burgdorferi and Treponema pallidum potentiates innate immune activation and induces gamma interferon production. Infect Immun. 2007:75:2046-62.

66. Schwartz I, Wormser GP, Schwartz JJ, Cooper D, Weissensee P, Gazumyan A, et al. Diagnosis of early Lyme disease by polymerase chain reaction amplification and culture of skin biopsies from erythema migrans lesions. J Clin Microbiol. 1992:30:3082-8.

67. Mulay VB, Caimano MJ, Iyer R, Dunham-Ems S, Liveris D, Petzke MM, et al. Borrelia burgdorferi bba74 is expressed exclusively during tick feeding and is regulated by both arthropod- and mammalian host-specific signals. J Bacteriol. 2009;191:2783-94.

68. Ojaimi C, Mulay V, Liveris D, lyer R, Schwartz I. Comparative transcriptional profiling of Borrelia burgdorferi clinical isolates differing in capacities for hematogenous dissemination. Infect Immun. 2005;73:6791-802.

69. Livak KJ, Schmittgen TD. Analysis of relative gene expression data using real-time quantitative PCR and the 2(-Delta Delta C(T)) Method. Methods. 2001;25:402-8.

\section{Submit your next manuscript to BioMed Central and we will help you at every step:}

- We accept pre-submission inquiries

- Our selector tool helps you to find the most relevant journal

- We provide round the clock customer support

- Convenient online submission

- Thorough peer review

- Inclusion in PubMed and all major indexing services

- Maximum visibility for your research

Submit your manuscript at www.biomedcentral.com/submit
(O) BioMed Central 